\title{
FIRM SURVIVAL, UNCERTAINTY, AND FINANCIAL FRICTIONS: IS THERE A FINANCIAL UNCERTAINTY ACCELERATOR?
}

\author{
JOSEPH P. BYRNE, MARINA-ELIZA SPALIARA and SERAFEIM TSOUKAS*
}

\begin{abstract}
Using a large panel of unquoted UK firms over the period 2000-2009, we examine the impact of firm-specific uncertainty on corporate failures. In this context we also distinguish between firms which are likely to be more or less dependent on bank finance as well as public and nonpublic companies. Our results document a significant effect of uncertainty on firm survival. This link is found to be more potent during the recent financial crisis compared with tranquil periods. We also uncover significant firm-level heterogeneity because the survival chances of bank-dependent and nonpublic firms are most affected by changes in uncertainty, especially during the recent global financial crisis. (JEL E44, F32, F34, G32)
\end{abstract}

\section{INTRODUCTION}

The global financial crisis had dire economic consequences for a host of public and private sector agents across advanced and emerging economies. The crisis was a time of heightened uncertainty, financial distress, and widespread firm closures. All firms continuing as going concerns however, with lower investment after a rise in uncertainty, may not be equivalent to some firms closing completely due to uncertainty. ${ }^{1}$ Reinforcing this effect, firms are more likely to experience bankruptcy and to be more susceptible to macroeconomic and firm specific uncertainty,

\footnotetext{
${ }^{*}$ We are grateful to two anonymous referees and Wesley W. Wilson (editor) for very helpful comments and suggestions. We also thank Mustafa Caglayan and Rebecca Riley and participants at the 2014 European Meetings of the Econometric Society, Toulouse School of Economics for comments on an earlier version of this paper. Any remaining errors are our own.

Byrne: Economics, School of Management and Languages, Heriot-Watt University, Edinburgh, Scotland EH14 4AS, UK. Phone +44 (0)131 451 3626, Fax +44 (0) 131451 3296, E-mail j.p.byrne@ @w.ac.uk

Spaliara: Economics, Adam Smith Business School, University of Glasgow, Glasgow, Scotland G12 8QQ, UK. Phone +44 (0)141 330 7596, Fax +44 (0) 141330 4939, E-mail marina.spaliara@glasgow.ac.uk

Tsoukas: Economics, Adam Smith Business School, University of Glasgow, Glasgow, Scotland G12 8QQ, UK. Phone +44 (0)141330 6325, Fax +44 (0) 141330 4939, E-mail serafeim.tsoukas@glasgow.ac.uk

1. It is a standard result in the theoretical literature that uncertainty is associated with a decline in economic activity (see Mishkin 2011). Dixit and Pindyck (1994) provide one appealing explanation for why irreversible investment is reduced by uncertainty.
}

in a situation in which they experience poor financial health (see Bernanke, Gertler, and Gilchrist 1996 and Ghosal and Loungani 2000). Whether researchers fully model the impact of uncertainty on economic activity depends upon, at least partly, whether firms survive or close their operations completely. Surprisingly there is limited empirical evidence regarding the effect of uncertainty on firm closure, for example during the recent financial crisis.

In this paper, we consider the role of firm-level uncertainty in firms' hazard of failure during economic downturns. More precisely, we generate a measure of firm-specific uncertainty that stems from firms' volatility in sales. Then we observe the most recent financial crisis which provides an interesting set-up to explore the role of uncertainty in firms' failure. Finally, we look at the financial health of the firm, reflected in the quality of its balance sheet. Our empirical work is based on an assessment of firm-specific uncertainty on firms' chances of failure using an unbalanced panel of 9,457 UK firms between 2000 and 2009. We employ annual firm-level data from the Financial Analysis Made Easy (FAME) database. A discrete proportional hazard model examines failure probability for firms with different balance sheet characteristics and exposure in micro and macro uncertainty. Then we take into account

\section{ABBREVIATIONS}

AIM: Alternative Investment Market FAME: Financial Analysis Made Easy

SMEs: Small- and Medium-Sized Enterprises 
firms' reliance on bank debt as well as their ownership structure (public or private).

In doing so, we contribute to the existing literature in three important ways. First, we investigate the link between uncertainty and firm survival, paying special attention to the most recent financial crisis. While there is a large and growing literature on the effects of uncertainty on firms' investment, capital structure, and inventories (see Baum, Stephan, and Talavera 2009; Baum, Caglayan, and Talavera 2010a, 2010b; Caglayan, Maioli, and Mateut 2012; Caglayan and Rashid 2014), less attention has been given to the important dimension of firm survival. Yet, the potential closure of a great number of businesses was one of the most visible threats to economic performance during the Great Recession. As far as we are aware, this study is the first to provide a systematic analysis of the link between uncertainty at the micro level, and corporate failures during the most recent global financial crisis.

Second, this paper accounts for the important dimension of firm heterogeneity, distinguishing between firms which are likely to be more or less dependent on bank finance. This is particularly important because UK banks interrupted their lines of credit during the crisis due to liquidity problems (Bell and Young 2010). This phenomenon was also evident in Europe as shown in the results of the EU bank lending survey which points to a substantial reduction in loan supply and increased lending standards that exposed bank dependent borrowers. Hence, identifying those companies which rely heavily on bank finance will allow us to provide a sharper test of the effect of uncertainty on firm survival. We also distinguish between public and private firms, because the latter are smaller and typically associated with the highest degree of information asymmetry. ${ }^{2}$

Third, we employ a much broader sample of firms than other studies in the literature. Our data-set is made up mainly by unlisted companies. Unlike previous studies which typically rely on listed companies (see for example Baum, Stephan, and Talavera 2009 and Baum, Caglayan, and Talavera 2010a, 2010b), we use a large panel of financial data on UK firms, over $98 \%$ of which are not quoted on the stock market. This characteristic is vitally important because these

2. There is evidence showing that the leverage of private UK manufacturing firms is more sensitive to firm-specific risk compared to their public counterparts (Caglayan and Rashid 2014). firms are more likely to suffer from information asymmetry problems and hence will be affected the most during extreme economic events.

To preview our results, we find significant evidence of the impact of uncertainty on firm survival in the UK using a broader sample of firms than is typically used in the literature. Indeed, the impact of uncertainty is more potent in the recent crisis period compared with the great moderation. Furthermore our data-set is able to uncover important heterogeneity in firm behavior. We identify that both more bank-dependent and nonpublic firms are greatly impacted by uncertainty, and this effect is magnified during the crisis. Overall, our evidence provides a key contribution to the literature on firm survival, uncertainty, and financial distress.

The rest of the article is set out as follows. In Section II, we provide a short discussion of the related literature. Section III presents the hypotheses and the empirical methods used. Section IV describes our data and presents some summary statistics. Sections V and VI illustrate our main empirical results and robustness tests. Section VII concludes.

\section{ECONOMIC BACKGROUND}

The theoretical and empirical literature confirms that uncertainty is associated with a decline in output, investment, and employment at the aggregate and disaggregate level. Significant contributions in this area include, for example, studies from Dixit and Pindyck (1994), Caballero (1999), and Bond and Van Reenen (2007). There is less work, however, on uncertainty and firm survival. Firms operating with less investment may not be equivalent to some firms closing completely due to uncertainty. That is to say, uncertainty may have different implications for the economy depending upon whether firms close or not, and hence different implications for longrun productive capacity of an economy. Bloom (2007, 2009) highlights how temporary uncertainty may be associated with a temporary downturn, but firms shall become active again once uncertainty subsides. Clearly, if firms are more susceptible to close down this will have implications for an economy's capacity to return to trend growth. The irreversibility channel of uncertainty therefore may be more potent when we consider the possibility that firms may close.

Although there is less work looking at uncertainty and firm survival, there is an established 
literature that examines uncertainty and firmlevel investment and R\&D: see Ghosal and Loungani (2000), Ghosal (2003), Bo and Lensin (2005), Baum, Caglayan, and Talavera (2010b), and Gilchrist, Sim, and Zakrajsek (2013). ${ }^{3}$

Bloom (2007) argues that uncertainty about future productivity and demand conditions will generate fluctuations in investment, hiring, and productivity. Higher uncertainty generates a temporary slowdown and bounce back as firms postpone activity and wait for uncertainty to subside. This effect is expected to be stronger during recessions. Dixit (1989) emphasizes the implications of an uncertain environment on entry and exit decisions of firms. In particular, Ghosal and Loungani (2000) show that uncertainty has a negative effect on investment, which is greater in small-firm-dominated industries. There is, however, limited empirical evidence regarding the effect of uncertainty on the UK economy particularly during the recent financial crisis, where uncertainty remained at an elevated level for an extended period of time. Using Granger causality tests, Haddow et al. (2013) argue that higher levels of uncertainty have been a factor restraining the UK recovery and may adversely affect growth. Denis and Kannan (2013) find in their vector autoregression analysis that uncertainty shocks have a significant impact on UK industrial production and gross domestic product and a somewhat limited effect on employment.

Our paper is also innovative because it considers the interrelation between firm survival, uncertainty, and financial shocks. It is generally accepted that following an adverse shock firms with poorer indicators of creditworthiness on their balance sheets will be more constrained than those that are considered creditworthy. Bernanke, Gertler, and Gilchrist (1996) present a theoretical channel whereby financial structure impacts firm behavior. The "flight to quality" by lenders, identified by Bernanke, Gertler, and Gilchrist (1996), underlies much of the dynamic adjustment observable in the macro-economy due to the credit channel following an adverse shock. Furthermore, the experience of UK corporates after the recent global financial crisis suggests that the financial system can generate an endogenous cycle (the accelerator) that propagates the initial shock over time, c.f. Bernanke, Gertler, and

3. For an extensive survey of microeconomic studies of investment and uncertainty see Bond and Van Reenen (2007). In particular, prominent work in the literature on firm investment and uncertainty include Leahy and Whited (1996), Guiso and Parigi (1999), and Bloom (2007).
Gilchrist (1996). Firms that initially have lower credit ratings and are refused external finance on this basis can find that their creditworthiness deteriorates further, putting future external finance further out of reach. The implication is that firms that are relatively constrained on the financial markets will face higher agency costs of borrowing — a higher "external premium"- - for raising capital from financial markets compared with the cost of internal finance funded from retained earnings (see also Bernanke and Gertler 1995). The external finance premium is inversely related to the firms' balance sheet, i.e., net worth, and to macroeconomic conditions, creating a countercyclical movement in the premium for external funds, which serves to amplify borrower's spending and economic activity in the financial accelerator (see Bernanke, Gertler, and Gilchrist 1996, 1999).

Ghosal and Loungani (2000) suggest the investment uncertainty nexus operates through capital market imperfections. Ghosal (2003) highlights that uncertainty and sunk costs at the industry level have a large negative impact on entry and exit probabilities of firms. ${ }^{4}$

The interrelationship between uncertainty, investment, and financial variables is discussed by Baum, Stephan, and Talavera (2009) and Baum, Caglayan, and Talavera (2010a, 2010b). The aforementioned studies identify an important channel by which uncertainty reduces firm access to credit, consequently leading to lower investment. Baum, Stephan, and Talavera (2009) identify a strong negative relationship between debt and macroeconomic uncertainty.

Gilchrist, Sim, and Zakrajsek (2013) also examine how macroeconomic uncertainty influences investment through financial frictions. Using macro and micro evidence, they establish that uncertainty impacts investment largely through credit spreads. Specifically, increases in uncertainty are associated with a widening of credit spreads and a decline in output. By delineating an alternative transmission mechanism, this calls into question the option value of waiting approach that exists in the literature. As a consequence this research proposes a specific channel by which uncertainty can impact upon firm survival.

Finally, Huynh, Petrunia, and Voia (2010) and Huynh and Petrunia (2010) present empirical evidence on the determinants of firm survival and

\footnotetext{
4. In this context, firm size may be an important determinant.
} 
growth, showing that firms' leverage matters for both activities and has a nonlinear impact on survival. Indeed, it may be the case that high leverage (or low profitability) does not have a persistent effect on economic activity, but the consequences of leverage for firm survival impinge upon recovery from recession. Such a view may contribute to our understanding of business cycles (Hall 2010). In the next section, we review specific research questions and discuss our empirical methods.

\section{HYPOTHESES AND METHODOLOGY}

\section{A. Research Questions}

This paper seeks to consider a number of research questions. First, we evaluate the direct effect of micro uncertainty on firms' failures for UK firms, the vast majority of which are not quoted on the stock market. After controlling for macro uncertainty and a number of firmspecific and financial indicators we might expect that firm-level uncertainty will lead to higher failure rates.

Second, we examine the impact of firmspecific uncertainty on the hazard of failure in and out of the most recent financial crisis. This can be tested through interactions between the measures of uncertainty and a timeperiod dummy, which is aimed at capturing the 2007-2009 global financial crisis. One should expect that firms will be more likely to fail during periods of economic uncertainty because firms have to postpone their activities. This effect might be amplified during economic downturns because firms find it extremely difficult to attract external funding at a reasonable cost and therefore have to cut down their activities.

Third, we test the probability of failure for different groups of firms in and out of the crisis, taking into account the uncertainty measures. Because of the nature of our data, we take into account firm heterogeneity by looking at the extent to which firms rely upon bank funding. As banks significantly restricted loans toward smalland medium-sized enterprises (SMEs) during the financial crisis, it is reasonable to suppose that bank-dependent firms are likely to have suffered more than their less bank-dependent counterparts. This argument is in line with Bell and Young (2010), who discuss statistics on loans to SMEs and syndicated loan spreads in the UK. They note that while investment-grade spreads peaked in 2008, they have fallen back after the crisis. We should expect to find that more bank-dependent firms will be more likely to fail when faced with higher levels of uncertainty compared with their less bank-dependent counterparts. Moreover, this link should be more important during the crisis. Finally, we intend to corroborate our results using the distinction between public and nonpublic firms. The latter group is more likely to be financially constrained and hence may respond more strongly to uncertainty compared with the former group of firms, especially during extreme economic events.

\section{B. Empirical Specifications}

Baseline Model. To evaluate the effect of uncertainty on the likelihood of firm failure, we use a complementary log-log model (cloglog), a discrete time version of the Cox proportional hazard model. This methodology is particularly indicated given that we are interested in investigating the determinants of the timing of firms' chances of failure. Considering this objective our analysis is related to the passage of time before the event of failure occurs. The cloglog model accounts for the incompletely observed lifespan of firms surviving past the sample and allows us to capture the exact time of failure, addressing in this way the potential right censoring bias. ${ }^{5}$ The assumption of the proportional hazard model is that the hazard ratio depends only on time at risk, $\theta_{0}(t)$ (the so-called baseline hazard) and on explanatory variables affecting the hazard independently of time, $\exp \left(\beta^{\prime} K\right)$. The hazard ratio is then given by:

$$
\theta(t, K)=\theta_{0}(t) \exp \left(\beta^{\prime} K\right)
$$

The discrete-time hazard function, $h(j, K)$, shows the interval hazard for the period between the beginning and the end of the $j$ th year after the first appearance of the firm. This hazard rate, which is the rate at which firms fail at time $t$ given that they have survived in $t-1$, takes the following form:

$$
h(j, K)=1-\exp \left[-\exp \left(\beta^{\prime} K+\gamma_{j}\right)\right]
$$

where we are particularly interested in identifying the $\beta$ parameters, which show the effect of the explanatory variables incorporated in vector $K$ on

5. To capture the particular nature of the data-set, given that it is collected on a yearly basis, the cloglog model is more appropriate than the standard Cox model (see Görg and Spaliara 2014). Also, see Jenkins (2005) for an excellent overview of complementary $\log -\log$ and proportional hazard models. 
the hazard rate. In the tables presented below, we report coefficients rather than hazard ratios (exponential coefficients). The interpretation of the coefficients is as follows. A positive coefficient indicates that an increase in the associated explanatory variable leads to an increase in the hazard of failure in any given year. A negative coefficient estimate suggests that the explanatory variable is negatively associated with the hazard and therefore reduces the probability of failure. When interpreting our results, it is useful to look at the exponentiated coefficients, which have the interpretation of the ratio of the hazard for one unit change in the explanatory variable. In our discussion of the findings, we will present detailed examples of how we calculate the magnitude of the coefficients. ${ }^{6}$

We set out a benchmark model to estimate how firms' probability of failure is affected by uncertainty and their financial conditions:

$$
\begin{aligned}
& h(j, X)=1-\exp \left[-\exp \left(\beta_{0}+\beta_{1}\right. \text { Sigma }\right. \\
& \left.\left.\quad+\beta_{2} X+\beta_{3} Y+\gamma_{j}\right)\right]
\end{aligned}
$$

where Sigma represents the uncertainty measured at the micro (firm) level. The sign and significance of $\beta_{1}$ shows the importance of uncertainty on the probability of firms' failure. Vectors $X$ and $Y$ denote a set of control variables that have been found to be influential in firm survival studies. We partition the control variables into financial and other explicators.

Measuring Firm-Specific Uncertainty. There is an extensive literature examining the impact of uncertainty in other contexts and we seek to exploit that literature. Several studies use uncertainty on forecast earnings or profits: von Kalckreuth (2000) and Lensink, Bo, and Sterken (1999). Baum, Caglayan, and Talavera (2010b) use a capital asset pricing model measure to identify the impact of firm uncertainty on investment. To measure firm uncertainty Leahy and Whited (1996) and Bloom, Bond, and Van Reenen (2001) use volatility of stock prices. Ghosal and Loungani (2000) use profit forecasting to predict future profit in order to assess the impact of uncertainty on investment. Sales have been employed

6. $\gamma_{j}$ is the log of the difference between the integrated baseline hazard evaluated at the end and the beginning of the interval. It, thus, captures duration dependence. We do not impose any restrictions on these parameters, rather we estimate a full set of gamma $_{j}$ time dummies. as a proxy for firm-specific uncertainty by Lensink, Bo, and Sterken (1999) and Caglayan, Maioli, and Mateut (2012) who test the effect of sales volatility on inventory investment and by Garcia-Vega, Guariglia, and Spaliara (2012) who assess the effect of uncertainty on exporting. ${ }^{7}$

The heterogeneity amongst firms in our data allows us to employ a proxy of firm-specific uncertainty using firms' sales in line with previous studies (Caglayan, Maioli, and Mateut 2012; Garcia-Vega, Guariglia, and Spaliara 2012; Lensink, Bo, and Sterken 1999; Morgan, Rime, and Strahan 2004). In particular, we construct our uncertainty measure by estimating first an AR(1) model of sales augmented with time and industry-specific dummies. ${ }^{8}$ To take into account the panel data nature of our data-set we employ a GMM system estimator (see Arellano and Bover 1995; Blundell and Bond 1998). We verify that the diagnostics do not indicate any problems regarding the choice and the relevance of our instruments. Uncertainty is then computed as the standard deviation of the firm's total real sales calculated over the 3 years preceding and including year $t .9,10$

Other Influences. $X$ is a vector of financial variables Leverage and Profitability. Both variables capture different aspects of the financial health of a firm. We control for firms' financial health motivated by the theoretical model of Clementi and Hopenhayn (2006) ${ }^{11}$ and previous empirical studies (Bridges and Guariglia

7. Other authors use firm surveys of expectations (see Guiso and Parigi 1999; Patillo 1998) or a theoretical measure of microeconomic uncertainty (Carlsson 2007).

8. Alternative measures of firm level of uncertainty can in principle be extracted from, for example, Confederation of British Industry survey data (see Mitchell, Mouratidis, and Weale 2007). However, the concordance of firms would present significant challenges and coverage may be incomplete for our unlisted firms. Moreover multivariate GARCH methods based upon the cross sectional data could be adopted, but this would present significant computational challenges given the short time dimension of the data.

9. We check the sensitivity of our results to using a different measure of sales uncertainty computed over the 4 years preceding and including year $t$ (see Section VI).

10. It should be noted that given the way in which we calculate uncertainty, this variable is not available for the years 2000 and 2001. For this reason, all regressions which contain our main measure of uncertainty are based on the sample 2002-2009.

11. Their model generates a role for capital structure in an asymmetric information setup. The theoretical frameworks on survival were first introduced by Hopehayn (1992) and Jovanovic (1982) without considering a role for moral hazard. 
2008; Bunn and Redwood 2003; Huynh, Petrunia, and Voia 2010). To begin with financial leverage (Leverage), which is measured as the ratio of total current liabilities over total assets, we note that high levels of existing debt are associated with a worse balance sheet situation, which would increase moral hazard and adverse selection problems, and lead to the inability of firms to obtain external finance at a reasonable cost (see Levin, Natalucci, and Zakrajsek 2004; Mizen and Tsoukas 2012). Zingales (1998) and Bridges and Guariglia (2008) argue that higher leverage results in higher failure probabilities. Accordingly, we expect a positive relationship between leverage and the probability of survival.

Profitability (Profitability) is defined as the ratio of the firm's profits before interests and tax to its total assets. We use this indicator to measure a firm's efficiency. It is widely accepted that internal funds can serve as a buffer to absorb unexpected losses, reducing the probability of insolvency and, therefore, the expected bankruptcy cost (see Bridges and Guariglia 2008; Bunn and Redwood 2003). We therefore expect to find profitability to decrease the probability of failure.

The covariates used in the vector $Y$ are all chosen in view of other work on firm survival. We add the firm size (Size) measured as the logarithm of real total assets. According to Geroski (1995), a firm's size plays an important role in determining firm failures. The argument is that large firms experience higher survival probabilities than their smaller counterparts because they have access to alternative sources of external finance and they are less informationally opaque. Thus large firms are less likely to fail than small firms (Clementi and Hopenhayn 2006; Dunne, Roberts, and Samuelson 1998). In our analysis, we expect to find a positive relationship between firm size and the probability of survival. We also include the age of the firm (Age) which measures the number of years since the firm's birth. Firms with an established track record are less likely to fail than those that are younger because they are usually more able to withstand past economic and financial downturns and therefore face a smaller liquidation risk. This would be the case both for domestic and multinational firms as noted by Görg and Strobl (2002). Consequently, we anticipate a negative relationship between age and the probability of failure.
In addition, we account for whether a firm is part of a larger corporation or a group (UK or foreign). Following the relevant literature, we construct the dummy variable Group, which takes the value one if a firm is part of a group, and zero otherwise. We expect to observe a negative relationship between this variable and the hazard of failure since group firms are likely to have better access to capital markets and to respond more quickly to shocks than single firms, due to better information processing (Bridges and Guariglia 2008). We also control for foreign ownership by using a dummy variable, Ownership, equal to one if the share of foreign ownership in a firm's equity exceeds $24.99 \%$, and zero otherwise. The evidence on the impact of foreign-owned firms on survival chances is mixed. ${ }^{12}$ Therefore, we should expect ownership to have a significant effect on failure but its sign will be determined by the data.

In vector $Y$ we also control for the macroeconomic conditions by adding the real exchange rate, which measures the exchange rate environment. Baggs, Beaulieu, and Fung (2009) document a negative association between survival and appreciation of the Canadian dollar. We expect the exchange rate (Exchange) to be positively associated with the firm's probability to fail. In addition, we control for aggregate uncertainty by using a policy uncertainty measure. This economic policy uncertainty measure for the UK is drawn from Baker, Bloom, and Davis (2013). It is constructed with a 50\% weight on a news-based component from the Financial Times and The Times newspapers (i.e., the mention of policy relevant terms) and $50 \%$ on Consensus Economics CPI and budget deficit forecaster disagreement. We expect higher levels of aggregate uncertainty to reduce firms' chances of survival. Finally, our model includes a full set of time, industry, and regional dummies. To obtain efficient estimators and unbiased standard errors we apply the Huber-White sandwich or robust estimator.

The Effect of the Crisis. To examine whether the hazard of failure differs in crisis years compared

12. Using data from Ireland and Indonesia, Görg and Strobl (2003) and Bernard and Sjöholm (2003), respectively, show that multinationals are more likely to exit than domestic firms. On the other hand, Blalock, Gertler, and Levine (2008), and Desai and Forbes (2008) find that global engagement improves firms' performance, and hence reduces their likelihood of failure. 
with tranquil periods, we augment Equation (3) with a financial crisis dummy (Crisis), which takes value one over the period 2007-2009, and zero otherwise. The financial crisis might have both a direct and an indirect impact on exit by magnifying the effect of uncertainty on firms' likelihood to fail.

$$
\begin{aligned}
& h(j, X)=1-\exp \left[-\exp \left(\beta_{0}+\beta_{1} \text { Sigma } *\right.\right. \\
& \text { Crisis }+\beta_{2} \text { Sigma } *(1-\text { Crisis })+\beta_{3} \\
& \text { Crisis } \left.\left.+\beta_{4} X+\beta_{5} Y+\gamma_{j}\right)\right]
\end{aligned}
$$

This test is motivated by the financialaccelerator-related hypothesis, according to which a deterioration in economic conditions negatively affects the health of firms' balance sheets. In these circumstances, firms facing increased levels of uncertainty might face a higher probability of failure during the crisis than outside. The sign and significance of the interacted terms will reveal the extent to which the impact of uncertainty on firm survival differs during tranquil and turbulent periods. We expect the effects of changes in the uncertainty on firms' chances of failure to be stronger during the crisis (i.e., we expect to observe that $\beta_{1}>\beta_{2}$ ). Finally, the crisis term is allowed to influence the probability of firm failure directly, judged from the sign and significance of the coefficient $\beta_{3}$.

Capturing Firm Heterogeneity. At the next stage we aim to assess whether changes in the level of uncertainty of firms in and out of the crisis will have a differential impact on their probability to fail, taking into account firm heterogeneity. To test this hypothesis we consider whether firms are more or less bank dependent. This test is motivated by recent evidence, both in the UK and the United States, which shows an increase in loan spreads during the crisis. In particular, Santos (2011) and Bell and Young (2010) document that banks interrupted their lines of credit due to liquidity problems, and thus we should expect bank dependent firms to be more severely affected during the financial crisis.

As in Kashyap, Stein, and Wilcox (1993) and Tsoukas (2011), we define bank-dependent firms based on their ratio of short-term debt to total debt (Mix). As short-term debt is predominantly made up of bank finance, this ratio is a good proxy of bank dependency. ${ }^{13}$ We modify Equation (3) to

13. To ensure that our results are robust, we carry out our estimations using an alternative definition of bank dependency based on short-term debt over current liabilities. contain interaction terms between the Mix ratio, the Crisis dummy, and the uncertainty measure. This yields the following empirical model:

(5)

$$
\begin{aligned}
& h(j, X)=1-\exp \left[-\exp \left(\beta_{0}+\beta_{1} \text { Sigma } *\right.\right. \\
& \text { Mix } * \text { Crisis }+\beta_{2} \text { Sigma } * \text { Mix } *(1-\text { Crisis }) \\
& \left.\left.+\beta_{3} \text { Mix }+\beta_{4} \text { Crisis }+\beta_{5} X+\beta_{6} Y+\gamma_{j}\right)\right]
\end{aligned}
$$

The sign and significance of the interacted terms will reveal whether firms more (less) likely to be bank dependent are less (more) likely to survive during the crisis compared with tranquil periods. We also allow both Mix and the crisis dummy to influence firms' chances of failure directly.

Finally, we run the above model distinguishing between public and private companies. According to our hypothesis, private firms are more likely to face financial constraints and hence may respond more strongly to uncertainty compared with public firms, especially during the crisis period. We expect, therefore, the behavior of private firms to match that of firms with high dependence on banks. ${ }^{14}$

\section{DATA AND SUMMARY STATISTICS}

\section{A. Data Description}

Our data set is drawn from the annual accounting reports taken from the FAME database, published by Bureau Van Dijk Electronic Publishing (BvDEP). We employ data for the period 2000-2009. ${ }^{15}$ We use a rich financial data-set that comprises mainly non-publicly traded UK manufacturing firms. Our database includes a majority of firms that are not traded on the stock market or quoted on alternative exchanges such as the Alternative Investment Market (AIM) and the Off-Exchange (OFEX) market. In fact, $98.2 \%$ of our sampled firms are private, while $1.8 \%$ are public companies. This figure is comparable with recent studies that employ the FAME

14. To ensure that bank dependence and the distinction between private/public firms control for different firm aspects, we control for firms' ownership structure when estimating models of bank dependency and vice versa.

15. A maximum of 10 years of complete data history can be downloaded at once. We have only selected firms that have unconsolidated accounts: this ensures that the majority of the firms in our data-set are relatively small. Moreover, it avoids the double counting of firms belonging to groups, which would be included in the data-set if firms with consolidated accounts were also part of it. 
TABLE 1

Detailed Statistics of Size Variables

\begin{tabular}{lccc}
\hline & $\begin{array}{c}\text { Employees } \\
\text { (1) }\end{array}$ & $\begin{array}{c}\text { Assets } \\
\text { (2) }\end{array}$ & $\begin{array}{c}\text { Turnover } \\
(\mathbf{3})\end{array}$ \\
\hline $25 \%$ & 31 & 2,249 & 4,000 \\
$50 \%$ & 85 & 4,748 & 9,586 \\
$75 \%$ & 234 & 13,932 & 25,442 \\
Observations & 85,231 & 123,535 & 78,760 \\
\hline
\end{tabular}

Notes: The table presents the median and the upper and lower quartiles of three size measures. "Employees" denotes the number of employees. "Assets" represents total assets. "Turnover" is the sum of domestic and overseas turnover. Assets and turnover are measured in thousands of UK sterling.

database to analyze UK firms' behavior (see Brav 2009; Caglayan and Rashid 2014; Michaely and Roberts 2012). Moreover, this is an appealing characteristic of the data as it allows our measures of uncertainty and financial health to display a wide degree of variation across observations in our sample. Having data on unquoted firms is particularly valuable in our case, as the unlisted companies are generally the smallest, youngest, and most-bank dependent firms. They are, therefore, more likely to be associated with the highest degree of information asymmetry and hence face an increased probability of failure, especially during extreme economic conditions.

Looking at the quartile distribution of various size measures in Table 1, we observe the variation over firms in terms of turnover, total assets, and number of employees. The median UK firm in our sample has an average of 85 employees, $£ 4.7$ million assets, and £9.5 million turnover which falls in the small and medium-sized enterprise category. ${ }^{16}$

To accurately construct our dependent variable we also take into account that some firms may exit due to mergers and acquisitions. Following Görg and Spaliara (2014), we employ Bureau Van Dijk's ZEPHYR database which contains information on mergers and acquisitions. Using ZEPHYR we are able to identify and drop those firms that are mistakenly coded as "failed" in our data. This ensures that our indicator variable has been accurately constructed to capture

16. In the UK, sections 382 and 465 of the Companies Act 2006 define a small and medium-sized enterprise (SME) for the purpose of accounting requirements. According to this, a small company is one that has a turnover of not more than $£ 6.5$ million, a balance sheet total of not more than $£ 3.26$ million, and not more than 50 employees. A medium-sized company has a turnover of not more than $£ 25.9$ million, a balance sheet total of not more than $£ 12.9$ million, and not more than 250 employees.
FIGURE 1

The Evolution of Firm-Specific Uncertainty

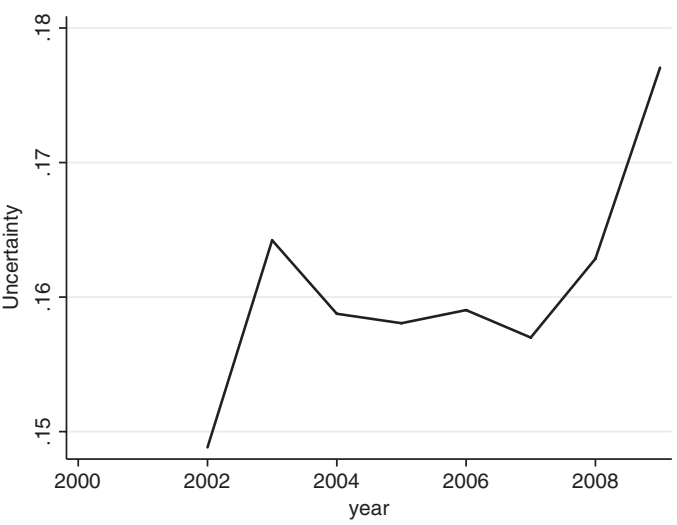

firms that failed and did not exit due to mergers and acquisitions.

Following normal selection criteria used in the literature, we drop firms that do not have complete records on our main regression. To control for the potential influence of outliers, we exclude observations in the $.5 \%$ tails for each of our regression variables. Our final panel, which is unbalanced, includes 9,457 firms corresponding to 51,101 observations.

\section{B. Descriptive Analysis}

As a way of preliminary analysis, we depict the evolution of micro and macro uncertainty in Figures 1 and 2. In Figure 1 we plot average values of the firm-specific uncertainty per annum. A period of quiescence during the Great Moderation is followed by a considerable increase in uncertainty associated with Lehman's collapse and the Global Financial Crisis in 2008 and 2009. We observe that both measures of uncertainty follow a similar trend over our sample period. ${ }^{17}$

We present summary statistics for the variables used in our empirical analysis in Table 2 . The figures are presented for all firms (column 1), for failed and surviving firms (columns 2 and 3 ) and for firms during and outside the crisis (columns 5 and 6) reporting means and standard deviations. Further, the $p$ values of a test for the equality of means between failing and surviving

17. Other indicators of economic uncertainty for the UK such as the Confederation of British Industry firm survey on demand uncertainty and the FTSE option-implied volatility paint a very similar picture. 


\section{FIGURE 2}

The Evolution of Aggregate Uncertainty

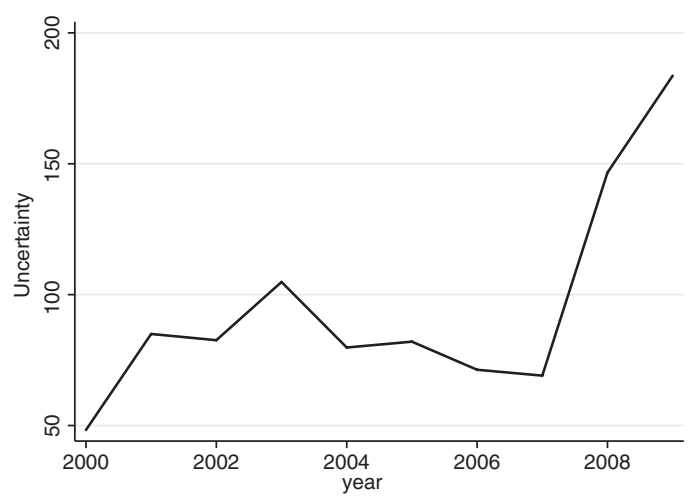

firms as well as crisis and noncrisis periods are presented in columns 4 and 7, respectively. We can see that the average failure rate in our sample is $16.1 \%$ which is much higher compared with previous UK studies (e.g., Bunn and Redwood 2003). The difference between our figures and theirs may probably be due to the fact that their sample covers a much earlier time period (up to 2003). It is therefore possible that failure rates have increased sharply over the most recent years. This is also consistent with statistics reported in the Office for National Statistics (ONS Business Demography Bulletins, 2007, 2008, and 2009).

When comparing failing and surviving firms, we note that the former exhibit a substantially higher firm-specific uncertainty. We also observe that surviving firms are less indebted and more profitable compared with failing firms. These statistics confirm previous empirical results (see Bridges and Guariglia 2008; Bunn and Redwood 2003; Zingales 1998) that firms which display healthier balance sheets are less likely to fail. In addition, we find that survivors are larger and older which is in line with previous empirical and theoretical research, which shows that the probability of exit decreases with firm size and age (e.g., Jovanovic 1982; Clementi and Hopenhayn

TABLE 2

Summary Statistics

\begin{tabular}{|c|c|c|c|c|c|c|c|}
\hline & $\begin{array}{l}\text { All Firms } \\
\text { (1) }\end{array}$ & $\begin{array}{c}\text { Fail }=1 \\
(2)\end{array}$ & $\begin{array}{c}\text { Fail }=0 \\
(3)\end{array}$ & $\begin{array}{l}\text { Diff. } \\
\text { (4) }\end{array}$ & $\begin{array}{c}\text { Crisis }=1 \\
\text { (5) }\end{array}$ & $\begin{array}{c}\text { Crisis }=0 \\
\text { (6) }\end{array}$ & $\begin{array}{l}\text { Diff. } \\
\text { (7) }\end{array}$ \\
\hline$\overline{\text { Fail }}$ & $\begin{array}{l}.161 \\
(.37)\end{array}$ & $\begin{array}{l}1.00 \\
(.00)\end{array}$ & $\begin{array}{l}.00 \\
(.00)\end{array}$ & - & $\begin{array}{l}.165 \\
(.37)\end{array}$ & $\begin{array}{l}.159 \\
(.36)\end{array}$ & .014 \\
\hline Sigma & $\begin{array}{l}.159 \\
(.16)\end{array}$ & $\begin{array}{l}.187 \\
(.19)\end{array}$ & $\begin{array}{l}.157 \\
(.16)\end{array}$ & .000 & $\begin{array}{l}.164 \\
(.16)\end{array}$ & $\begin{array}{l}.158 \\
(.17)\end{array}$ & .000 \\
\hline Leverage & $\begin{array}{l}.466 \\
(.27)\end{array}$ & $\begin{array}{l}.527 \\
(.31)\end{array}$ & $\begin{array}{l}.459 \\
(.27)\end{array}$ & .000 & $\begin{array}{l}.440 \\
(.28)\end{array}$ & $\begin{array}{l}.475 \\
(.27)\end{array}$ & .000 \\
\hline Profitability & $\begin{array}{l}.076 \\
(.16)\end{array}$ & $\begin{array}{l}.037 \\
(.19)\end{array}$ & $\begin{array}{l}.081 \\
(.16)\end{array}$ & .000 & $\begin{array}{l}.088 \\
(.17)\end{array}$ & $\begin{array}{l}.072 \\
(.16)\end{array}$ & .000 \\
\hline Size & $\begin{array}{l}3.953 \\
(1.38)\end{array}$ & $\begin{array}{l}3.728 \\
(1.29)\end{array}$ & $\begin{array}{l}3.984 \\
(1.39)\end{array}$ & .000 & $\begin{array}{l}4.040 \\
(1.32)\end{array}$ & $\begin{array}{l}3.922 \\
(1.41)\end{array}$ & .000 \\
\hline Age & $\begin{array}{l}25.048 \\
(23.01)\end{array}$ & $\begin{array}{l}24.606 \\
(23.47)\end{array}$ & $\begin{array}{l}25.133 \\
(22.92)\end{array}$ & .000 & $\begin{array}{l}28.396 \\
(22.64)\end{array}$ & $\begin{array}{l}23.602 \\
(23.02)\end{array}$ & .000 \\
\hline Group & $\begin{array}{l}.212 \\
(.41)\end{array}$ & $\begin{array}{l}.099 \\
(.29)\end{array}$ & $\begin{array}{l}.233 \\
(.42)\end{array}$ & .000 & $\begin{array}{l}.210 \\
(.41)\end{array}$ & $\begin{array}{l}.213 \\
(.41)\end{array}$ & .325 \\
\hline Ownership & $\begin{array}{l}.174 \\
(.38)\end{array}$ & $\begin{array}{l}.083 \\
(.27)\end{array}$ & $\begin{array}{l}.190 \\
(.39)\end{array}$ & .000 & $\begin{array}{l}.173 \\
(.37)\end{array}$ & $\begin{array}{l}.173 \\
(.38)\end{array}$ & .795 \\
\hline Exchange & $\begin{array}{l}96.693 \\
(11.57)\end{array}$ & $\begin{array}{c}96.585 \\
(5.01)\end{array}$ & $\begin{array}{c}96.714 \\
(4.95)\end{array}$ & .130 & $\begin{array}{c}84.229 \\
(9.20)\end{array}$ & $\begin{array}{c}102.081 \\
(7.68)\end{array}$ & .000 \\
\hline Policy & $\begin{array}{l}97.539 \\
(37.59)\end{array}$ & $\begin{array}{l}97.899 \\
(37.89)\end{array}$ & $\begin{array}{l}97.470 \\
(37.53)\end{array}$ & .110 & $\begin{array}{l}140.106 \\
(38.49)\end{array}$ & $\begin{array}{l}79.141 \\
(15.70)\end{array}$ & .000 \\
\hline Observations & 51,101 & 4,491 & 46,610 & & 16,854 & 34,247 & \\
\hline
\end{tabular}

Notes: The table presents sample means. Standard deviations are reported in parentheses. Fail is a dummy that equals one if the firm fails, and zero otherwise. Crisis is a dummy representing the recent crisis and takes the value one in years 2007-2009, and zero otherwise. Diff. is the $p$ value of the test statistic for the equality of means between failing and nonfalling firms (columns 1 and 2) as well as between crisis and noncrisis periods (columns 5 and 6). Sigma is a measure of firm-specific uncertainty. Leverage is measured as the firm's total current liabilities to assets ratio. Profitability is the ratio of the firm's profits before interest and tax to its total assets. Size is denoted by the log of real assets. Age is defined as the difference between the present year and the firm's date of incorporation. Group is a dummy variable equal to one if the firm is part of a group UK or foreign, and zero otherwise. Ownership is a dummy equal to one if the share of foreign ownership in a firm's equity exceeds $25 \%$, and zero otherwise. Exchange is the real effective exchange rate. Policy is a measure of aggregate uncertainty. Firm-specific variables are measured in thousands of UK sterling. 
2006). Furthermore, survivors are more likely to be part of a UK group and foreign owned. These differences between sub-samples are statistically significant in all cases.

Moving to the comparison between crisis and out of crisis periods (columns 5 and 6), we note that the average failure rate and the firm-specific uncertainty are higher during the crisis. These differences are statistically significant in both cases. In addition, during the crisis firms display lower values of leverage and higher profitability. This is consistent with the notion that firms took a substantial amount of short-term debt in the precrisis period and perhaps were unable to extend it further in the later years of our sample. The latter statistic is in line with ONS data on profitability for UK manufacturing firms. ${ }^{18} p$ Values suggest that differences between sub-samples are statistically significant in all but one case.

Taken together, these summary statistics suggest that there is a significant correlation between firms' failure rates, firm-specific uncertainty, and firms' financial health. This relationship is even more important during the global financial crisis. It remains to be seen, though, whether these preliminary findings continue to hold when we control for a number of factors which are known to play a role in determining firms' survival chances. In the sections that follow, we test within a formal regression analysis framework whether the sensitivity of survival to firm-specific uncertainty is significantly higher during the financial crisis compared with tranquil periods.

\section{MAIN RESULTS}

\section{A. Firm-Specific Uncertainty and the Financial Crisis}

To assess the role of the firm-specific uncertainty in firms' hazard of failure, we focus on the direct and indirect (through interactions with the crisis dummy) impact on the probability of survival. We specify a time-period dummy variable to indicate that firms faced the 2007-2009 financial crisis, and this crisis dummy takes the value of one during this period, and the value zero otherwise. Results are reported in Table 3. In column 1 , we include firm-specific uncertainty along with time, industry, and regional dummies. In the subsequent column, uncertainty is included along with a number of firm-specific and other control

18. See the ONS Statistical Bulletin for details on UK firms' profitability.
TABLE 3

Firm Survival and Uncertainty

\begin{tabular}{|c|c|c|c|}
\hline & (1) & (2) & (3) \\
\hline Sigma & $\begin{array}{l}.869^{* * *} \\
(13.96)\end{array}$ & $\begin{array}{l}.782^{* * *} \\
(11.38)\end{array}$ & \\
\hline Sigma* Crisis & & & $\begin{array}{c}1.152^{* * * *} \\
(5.74)\end{array}$ \\
\hline Sigma* (1-Crisis) & & & $\begin{array}{l}.741^{* * * *} \\
(10.21)\end{array}$ \\
\hline Crisis & & & $\begin{array}{l}.245^{* * * *} \\
(3.78)\end{array}$ \\
\hline Leverage & & $\begin{array}{l}.009^{*} \\
(1.86)\end{array}$ & $\begin{array}{l}.009^{*} \\
(1.85)\end{array}$ \\
\hline Profit & & $\begin{array}{l}-.024^{*} \\
(-1.89)\end{array}$ & $\begin{array}{l}-.024^{*} \\
(-1.87)\end{array}$ \\
\hline Size & & $\begin{array}{l}-.182^{* * * *} \\
(-15.47)\end{array}$ & $\begin{array}{l}-.182^{* * * *} \\
(-15.47)\end{array}$ \\
\hline Age & & $\begin{array}{l}-.002^{* *} \\
(-2.47)\end{array}$ & $\begin{array}{l}-.002^{* *} \\
(-2.47)\end{array}$ \\
\hline Group & & $\begin{array}{l}-.990^{* * *} \\
(-19.33)\end{array}$ & $\begin{array}{l}-.990^{* * * *} \\
(-19.35)\end{array}$ \\
\hline Ownership & & $\begin{array}{l}-.620^{* * * *} \\
(-12.59)\end{array}$ & $\begin{array}{l}-.620^{* * * *} \\
(-12.59)\end{array}$ \\
\hline Exchange & & $\begin{array}{c}6.469^{* * * *} \\
(3.76)\end{array}$ & $\begin{array}{c}6.478^{* * *} \\
(3.76)\end{array}$ \\
\hline Policy & & $\begin{array}{c}1.499^{* * * *} \\
(3.71)\end{array}$ & $\begin{array}{c}1.501^{* * * *} \\
(3.71)\end{array}$ \\
\hline Observations & 51,762 & 51,101 & 51,101 \\
\hline $\begin{array}{l}\text { Log-likelihood } \\
\text { Test of equality ( } p \text { value) }\end{array}$ & $-14,101$ & $-13,031$ & $-13,029$ \\
\hline Sigma & & & .053 \\
\hline
\end{tabular}

Notes: Proportional hazard model results are reported. The dependent variable is a dummy equal to 1 if the firm fails, and 0 otherwise. Robust $z$-statistics are presented in parentheses. The $F$ test of equality for Sigma refers to the test of equality between Sigma*Crisis and Sigma*(1Crisis). Time, industry, and regional dummies are included in all models. at $1 \%$.

*Significant at $10 \%$; ${ }^{* *}$ significant at $5 \%$; ${ }^{* * *}$ significant

variables to assess the consequences of a ceteris paribus increase in uncertainty on the probability of firms' failure. Column 3 explores whether in addition to having a direct effect on firms' chances of survival, the financial crisis may also have an asymmetric response through interactions with the firm-specific uncertainty. ${ }^{19}$

To begin with, the coefficient on the firmspecific uncertainty exerts a positive and highly significant effect on failure. This finding is not only statistically but also economically important. The predicted probability of exit, evaluated at the mean of the independent variables, is $9 \%$. The coefficient on the firm-specific

19. Time dummies are included in all models, with the exception of the crisis years 2007-2009 when the crisis term is included on its own. 
uncertainty suggests that the probability of failure is rising, which translates to an increase in the predicted exit probability by around 12.5 percentage points. This is calculated at the mean exit probability of $9 \%$, using the exponentiated coefficient: $\exp (.869)-1=1.384$, $(1.384 * 9)=12.46 \% .^{20}$ Consistent with our expectations, increases in the firm-specific uncertainty will therefore negatively affect firms' survival prospects.

The point estimates on the control and financial variables behave as conjectured. Specifically, the coefficient associated with the aggregate uncertainty is positive and precisely determined, suggesting that higher levels of macro uncertainty are likely to increase the incidence of corporate failure. In addition, firms which are less indebted and more profitable are less likely to fail. Larger and older firms are also less at risk compared to smaller and younger companies that lack track record reputation. These results are in line with a number or previous studies (Zingales 1998; Bridges and Guariglia 2008; Görg and Spaliara 2014). Regarding the remaining control indicators, being part of a group and being foreign owned improve the survival prospects of firms (Bridges and Guariglia 2008). Lastly, as in Baggs, Beaulieu, and Fung (2009), a stronger local currency raises the probability of firm failure, while higher levels of aggregate uncertainty will raise the probability of failure. This is consistent with the existing evidence of negative impact of uncertainty on investment at micro level, see for example Bloom, Bond, and Van Reenen (2007) and Baum, Caglayan, and Talavera (2010b) for a panel of UK and US firms respectively.

Moving to the interaction terms, as shown in column 3 of Table 3, we gauge the differential role of microeconomic uncertainty in firm survival. In particular, we find that uncertainty has a more potent role during the crisis, because the coefficient on the interaction with the crisis dummy is positive and highly significant. The difference in this effect across the two time periods is economically important: a $1 \%$ increase in the firm-specific uncertainty would raise the hazard of failure by $19.45 \%$ over the crisis period 2007-2009, but only by $9.88 \%$ during tranquil periods. The $p$ value for the equality

20. As already noted, the hazard ratio can be calculated as $\exp (k)$ for the $k$ th regressor. Hence, in column 1 the coefficient on sigma is .869 , which is equivalent to a hazard ratio of $\exp (.869)-1=1.384$. of the coefficients indicates a statistically significant difference between the two coefficients. In addition, we find that the crisis dummy attains a positive and highly significant coefficient indicating that during the crisis period the probability of firm failure is higher compared with tranquil times.

\section{B. The Role of Firm-Level Heterogeneity}

Bank-Dependent Firms. Having identified a significant relationship between firm-specific uncertainty, the financial crisis, and probability of failure, we now explore whether this relationship differs when we consider firms which are likely to be dependent on bank finance. According to our hypothesis, bank-dependent firms have had their lines of credit dramatically reduced during the recent crisis. Given their inability to finance their activities from external sources (e.g., stocks or bond finance), they are likely to have suffered more than their less bank-dependent counterparts. Consequently, we anticipate the effect of firm-specific uncertainty to be stronger for firms exhibiting a greater reliance on bank debt compared with their less-bank dependent counterparts. Therefore, in Table 4 we explore the impact of interactions between crisis and noncrisis periods and firmspecific uncertainty for firms that are more or less likely to be categorized as bank dependent.

Focusing on rows 1 and 2 of Table 4, we observe that as firms rely more on bank debt, the measure of firm-specific uncertainty displays a larger coefficient during the crisis than outside. A test for the equality of the coefficients is reported at the foot of the table. It shows that the differences in the coefficients on the interactions during and outside the crisis are statistically significant. To put it differently, the greater sensitivities of firm survival to changes in the firm-specific uncertainty documented for more-bank firms during the crisis than outside suggests that higher levels of uncertainty coupled with limited access to credit may play a detrimental role in explaining the high number of failures in the UK during the most recent financial crisis.

With respect to the other control variables, it is worth noting that the crisis dummy and the Mix ratio are both positive but quantitatively unimportant. Lastly, the remaining firm-specific and macroeconomic variables retain their significance, with the only exception being the private dummy which enters with the expected positive sign but it is not precisely determined. 
TABLE 4

Uncertainty, Bank Dependency, and the Crisis

\begin{tabular}{|c|c|}
\hline Sigma* Mix ${ }^{*}$ Crisis & $\begin{array}{c}1.583^{* * * *} \\
(6.73)\end{array}$ \\
\hline Sigma ${ }^{*} \operatorname{Mix}^{*}$ (1-Crisis) & $\begin{array}{c}.845^{* * * *} \\
(8.23)\end{array}$ \\
\hline Crisis & $\begin{array}{l}.242 \\
(.77)\end{array}$ \\
\hline Mix & $\begin{array}{c}.063 \\
(1.29)\end{array}$ \\
\hline Private & $\begin{array}{l}.061 \\
(.65)\end{array}$ \\
\hline Leverage & $\begin{array}{c}.007 \\
(1.61)\end{array}$ \\
\hline Profit & $\begin{array}{l}-.025^{*} \\
(-1.93)\end{array}$ \\
\hline Size & $\begin{array}{l}-.180^{* * * *} \\
(-15.37)\end{array}$ \\
\hline Age & $\begin{array}{c}-.002^{* * * *} \\
(-2.75)\end{array}$ \\
\hline Group & $\begin{array}{l}-.993^{\text {**** }} \\
(-19.38)\end{array}$ \\
\hline Ownership & $\begin{array}{l}-.619^{* * * *} \\
(-12.54)\end{array}$ \\
\hline Exchange & $\begin{array}{c}6.438^{* * * *} \\
(3.75)\end{array}$ \\
\hline Policy & $\begin{array}{c}1.491^{* * * *} \\
(3.70)\end{array}$ \\
\hline Observations & 51,101 \\
\hline Log likelihood & $-12,983$ \\
\hline Test of equality ( $p$ value) & \\
\hline Sigma Mix & .003 \\
\hline
\end{tabular}

Notes: Proportional hazard model results are reported. The dependent variable is a dummy equal to 1 if the firm fails, and 0 otherwise. Robust $z$-statistics are presented in parentheses. Sigma*Mix refers to the test of equality between Sigma*Mix*Crisis and Sigma*Mix*(1-Crisis). Time, industry, and regional dummies are included in all models. at $1 \%$.

*Significant at $10 \% ;{ }^{* *}$ significant at $5 \% ;{ }^{* * *}$ significant

Public Versus Private Firms. In a final exploration we investigate whether the behavior of public firms is different from that of private firms. Our rationale for the categorization of public versus nonpublic firms stems from the fact that public companies are typically larger and less informationaly opaque. Private companies, on the other hand, face a higher degree of information asymmetry and tend to be more financially constrained. As a consequence, for these firms lenders typically command higher borrowing costs resulting to higher spreads (see Brav 2009; Caglayan and Rashid 2014). We hypothesize, therefore, that private firms are more likely to respond more strongly to uncertainty compared with public firms, especially during the crisis period. Hence, we interact a dummy variable representing the private firms (Private)
TABLE 5

Uncertainty, Ownership Structure, and the Crisis

\begin{tabular}{|c|c|}
\hline Sigma $^{*}$ Private ${ }^{*}$ Crisis & $\begin{array}{c}1.105^{* * * *} \\
(5.36)\end{array}$ \\
\hline Sigma* Private ${ }^{*}$ (1-Crisis) & $\begin{array}{c}.715^{* * * *} \\
(9.67)\end{array}$ \\
\hline Sigma $^{*}(1-\text { Private })^{*}$ Crisis & $\begin{array}{c}.653^{* * * *} \\
(3.91)\end{array}$ \\
\hline Sigma $^{*}(1-$ Private $) *(1-$ Crisis $)$ & $\begin{array}{c}1.056^{* * * *} \\
(2.96)\end{array}$ \\
\hline Crisis & $\begin{array}{l}.245 \\
(.78)\end{array}$ \\
\hline Mix & $\begin{array}{l}.237^{* * * *} \\
(5.22)\end{array}$ \\
\hline Private & $\begin{array}{c}.31 \\
(1.15)\end{array}$ \\
\hline Leverage & $\begin{array}{l}.008 \\
(1.63)\end{array}$ \\
\hline Profit & $\begin{array}{l}-.024^{*} \\
(-1.87)\end{array}$ \\
\hline Size & $\begin{array}{l}-.179^{* * * *} \\
(-15.36)\end{array}$ \\
\hline Age & $\begin{array}{l}-.002^{* *} \\
(-2.44)\end{array}$ \\
\hline Group & $\begin{array}{l}-.992^{* * * *} \\
(-19.38)\end{array}$ \\
\hline Ownership & $\begin{array}{l}-.617^{* * * *} \\
(-12.53)\end{array}$ \\
\hline Exchange & $\begin{array}{c}6.475^{* * * *} \\
(3.76)\end{array}$ \\
\hline Policy & $\begin{array}{c}1.500^{* * * *} \\
(3.71)\end{array}$ \\
\hline Observations & 51,101 \\
\hline Log likelihood & $-12,956$ \\
\hline Test of equality ( $p$ value) & \\
\hline Sigma* Private & .074 \\
\hline Sigma*(1-Private) & .309 \\
\hline Sigma* Crisis & .070 \\
\hline Sigma* (1-Crisis) & .347 \\
\hline
\end{tabular}

Notes: Proportional hazard model results are reported. The dependent variable is a dummy equal to 1 if the firm fails, and 0 otherwise. Robust $z$-statistics are presented in parentheses. Sigma*Private refers to the test of equality between Sigma*Private*Crisis and Sigma* Private*(1-Crisis). Sigma*(1-Private) refers to the test of equality between Sigma*(1-Private)*Crisis and Sigma* (1-Private)*(1-Crisis). Sigma*Crisis refers to the test of equality between Sigma*Private*Crisis and Sigma* $(1-\text { Private })^{*}$ Crisis. Finally, Sigma*(1-Crisis) refers to the test of equality between Sigma*Private*(1-Crisis) and Sigma*(1Private)*(1-Crisis). Time, industry, and regional dummies are included in all models. at $1 \%$.

Significant at $10 \% ;{ }^{* *}$ significant at $5 \% ;{ }^{* * *}$ significant

with crisis and noncrisis periods and our measure of firm-specific uncertainty.

The results are reported in Table 5. For private firms there is a significant difference in response compared to public firms. Firm-specific uncertainty is a highly significant determinant of firm survival during the crisis compared to tranquil periods. The response of public firms matches 
that of the less bank-dependent firms reported above. When we consider public firms both in and out of the crisis, we find that there is no significantly different response in crisis with respect to uncertainty. We also note that the Mix ratio attains a positive coefficient which is significant at the $1 \%$ level. This finding shows that bank dependency affects the hazard rate directly since greater levels of bank reliance are likely to increase the probability of firm failure. We conclude that public and private firms may face different credit supply conditions based on their specific characteristics, and responded differently during the most recent crisis.

\section{ROBUSTNESS TESTS}

\section{A. Re-Defining Firm-Specific Uncertainty}

Thus far, we have used the 3-year moving standard deviation of the unpredictable part of sales to generate our uncertainty measure. To check the robustness of our results, we follow Caglayan, Maioli, and Mateut (2012) and construct the firmspecific uncertainty measure using a 4-year moving standard deviation (Sigma2). ${ }^{21}$

The results are reported in Table 6. In agreement with our main results, we show that the firm-specific uncertainty is more important in predicting firm failures during the crisis compared with tranquil times. In addition, we find that bank-dependent firms' survival chances are affected significantly more by changes in uncertainty during the crisis compared with more tranquil periods. In sum, we argue that our main findings are robust to an alternative definition of firm-specific uncertainty.

\section{B. An Alternative Definition for Bank Dependency}

To ensure the robustness of our findings, we re-define the variable indicating firms' reliance on bank debt using the ratio of short-term debt to total current liabilities (Mix2). The results are reported in Table 7 . Once again, we find that the crisis intensified the effects of uncertainty and firms that were bank dependent faced significantly higher chances of failure compared with less bank-dependent firms. These results suggest that our main findings are robust to using a different definition for the bank dependency.

21. We also experimented with measuring firm-specific uncertainty using firms' real sales calculated over all years
TABLE 6

Robustness: Alternative Definition of Uncertainty

\begin{tabular}{|c|c|c|}
\hline & (1) & (2) \\
\hline Sigma $2^{*}$ Crisis & $\begin{array}{l}.717^{* * * *} \\
(6.07)\end{array}$ & \\
\hline Sigma2* (1-Crisis) & $\begin{array}{l}.419^{* * * *} \\
(4.64)\end{array}$ & \\
\hline Crisis & $\begin{array}{l}.279^{* * * *} \\
(3.69)\end{array}$ & $\begin{array}{l}.227 \\
(.69)\end{array}$ \\
\hline Sigma2 ${ }^{*}$ Mix $^{*}$ Crisis & & $\begin{array}{l}.890^{* * * *} \\
(5.96)\end{array}$ \\
\hline Sigma2* Mix* (1-Crisis) & & $\begin{array}{l}.520^{* * * *} \\
(6.26)\end{array}$ \\
\hline Mix & & $\begin{array}{l}.104^{*} \\
(1.92)\end{array}$ \\
\hline Leverage & $\begin{array}{c}.017^{* * * *} \\
(3.26)\end{array}$ & $\begin{array}{l}.015^{* *} \\
(2.90)\end{array}$ \\
\hline Profit & $\begin{array}{l}-.018 \\
(-1.32)\end{array}$ & $\begin{array}{l}-.019 \\
(-1.18)\end{array}$ \\
\hline Size & $\begin{array}{l}-.206^{* * *} \\
(-15.48)\end{array}$ & $\begin{array}{l}-.204^{* * * *} \\
(-15.31)\end{array}$ \\
\hline Age & $\begin{array}{l}-.002^{*} \\
(-1.89)\end{array}$ & $\begin{array}{l}-.002^{* *} \\
(-2.16)\end{array}$ \\
\hline Group & $\begin{array}{l}-.950^{* * * *} \\
(-16.42)\end{array}$ & $\begin{array}{l}-.946^{* * *} \\
(-16.37)\end{array}$ \\
\hline Ownership & $\begin{array}{l}-.550^{* * *} \\
(-10.16)\end{array}$ & $\begin{array}{l}-.555^{* * *} \\
(-10.15)\end{array}$ \\
\hline Exchange & $\begin{array}{c}6.019^{* * * *} \\
(3.67)\end{array}$ & $\begin{array}{c}6.005^{* * * *} \\
(3.67)\end{array}$ \\
\hline Policy & $\begin{array}{c}1.393^{* * * *} \\
(3.62)\end{array}$ & $\begin{array}{c}1.391^{* * * *} \\
(3.61)\end{array}$ \\
\hline Private & & $\begin{array}{l}.065 \\
(.61)\end{array}$ \\
\hline Observations & 44,559 & 44,559 \\
\hline $\begin{array}{l}\text { Log likelihood } \\
\text { Test of equality ( } p \text { value) }\end{array}$ & $-10,472$ & $-10,473$ \\
\hline Sigma2 & .055 & \\
\hline Sigma2*Mix & & .027 \\
\hline
\end{tabular}

Notes: Proportional hazard model results are reported. The dependent variable is a dummy equal to 1 if the firm fails, and 0 otherwise. Robust $z$-statistics are presented in parentheses. Sigma2*Mix refers to the test of equality between Sigma2*Mix*Crisis and Sigma2*Mix*(1Crisis). Time, industry, and regional dummies are included in all models. at $1 \%$.

${ }^{*}$ Significant at $10 \% ;{ }^{* *}$ significant at $5 \%$; ${ }^{* * *}$ significant

\section{CONCLUSIONS}

It is well established in the theoretical and empirical literature that uncertainty has negative consequences for economic activity. However, there is some debate about the exact mechanism by which uncertainty affects the economy. The recent financial crisis has highlighted that violations of Modigliani-Miller theorem may

preceding and including year $t$. Our results were robust to this modification. 
TABLE 7

Robustness: Alternative Definition of Bank Dependency

\begin{tabular}{|c|c|}
\hline Sigma ${ }^{*}$ Mix $2^{*}$ Crisis & $\begin{array}{c}1.670^{* * * * *} \\
(5.47)\end{array}$ \\
\hline Sigma $^{*} \operatorname{Mix} 2^{*}(1-C r i s i s)$ & $\begin{array}{c}1.007^{* * * *} \\
(8.21)\end{array}$ \\
\hline Crisis & $\begin{array}{l}.243 \\
(.76)\end{array}$ \\
\hline Mix2 & $\begin{array}{c}-.071 \\
(-1.10)\end{array}$ \\
\hline Private & $\begin{array}{l}.056 \\
(.60)\end{array}$ \\
\hline Leverage & $\begin{array}{l}.007 \\
(1.60)\end{array}$ \\
\hline Profit & $\begin{array}{l}-.024^{*} \\
(-1.89)\end{array}$ \\
\hline Size & $\begin{array}{l}-.185^{* * * *} \\
(-16.65)\end{array}$ \\
\hline Age & $\begin{array}{c}-.002^{3 *} \\
(-2.82)\end{array}$ \\
\hline Group & $\begin{array}{l}-.991^{* * *} \\
(-19.36)\end{array}$ \\
\hline Ownership & $\begin{array}{l}-.623^{* * * *} \\
(-12.64)\end{array}$ \\
\hline Exchange & $\begin{array}{c}6.438^{* * * *} \\
(3.74)\end{array}$ \\
\hline Policy & $\begin{array}{c}1.492^{* * * *} \\
(3.69)\end{array}$ \\
\hline Observations & 51,101 \\
\hline $\begin{array}{l}\text { Log likelihood } \\
\text { Test of equality ( } p \text { value) }\end{array}$ & $-13,044$ \\
\hline $\begin{array}{l}\text { Test of equality ( } p \text { value) } \\
\text { Sigma }^{*} \text { Mix } 2\end{array}$ & .037 \\
\hline
\end{tabular}

Notes: Proportional hazard model results are reported. The dependent variable is a dummy equal to 1 if the firm fails, and 0 otherwise. Robust $z$-statistics are presented in parentheses. Sigma*Mix2 refers to the test of equality between Sigma*Mix $2 *$ Crisis and Sigma*Mix $2 *(1-$ Crisis). Time, industry, and regional dummies are included in all models. at $1 \%$.

*Significant at $10 \%$;* significant at 5\%; *** significant

be more transparent due to the specific banking nature of the Great Financial Crisis. And while stock markets did suffer, the impact was much more temporary. Financial markets were acting as an accelerator or amplifier of economic shocks, including uncertainty.

One popular idea is financial conditions accelerate the uncertainty impact on the economy. This paper sought to examine the uncertainty-firm survival nexus, with particular reference to financial interactions. Using a large firm-level data set we consider how financial conditions may have altered during the recent financial crisis, over and above the effects of firm-level uncertainty. We also explore whether bank-dependent and private companies are impacted to a greater extent by uncertainty. It may be reasonable to expect that firms exhibiting greater reliance on bank debt and nonpublic firms shall be more sensitive to uncertainty, for example due to an increase in the size of their external finance premium or the extent of available credit.

Our results document a significant effect of uncertainty on firm survival. This link is found to be more potent during the recent financial crisis compared with tranquil periods. We also uncover significant firm-level heterogeneity because the survival chances of bank-dependent and nonpublic firms are most affected by changes in uncertainty, especially during the recent global financial crisis. Our findings are of interest to policy makers who should take into account the response of firms to uncertainty when they contemplate policies that will make finance to companies more readily available.

\section{REFERENCES}

Arellano, M., and O. Bover. "Another Look at the Instrumental Variable Estimation of Error Components Models." Journal of Econometrics, 68, 1995, 29-51.

Baggs, J., E. Beaulieu, and L. Fung. "Firm Survival, Performance, and the Exchange Rate." Canadian Journal of Economics, 42, 2009, 393-421.

Baker, S., N. Bloom, and S. Davis. "Measuring Economic Policy Uncertainty." Chicago Booth Working Paper No. 13-02. Accessed June 15, 2015. http://www. policyuncertainty.com, 2013.

Baum, C., A. Stephan, and O. Talavera. "The Effects of Uncertainty on the Leverage of Non-Financial Firms." Economic Inquiry, 47, 2009, 216-25.

Baum, C., M. Caglayan, and O. Talavera. "On the Investment Sensitivity of Debt under Uncertainty." Economics Letters, 106, 2010a, 25-27.

- "On the Sensitivity of Firms' Investment to Cash Flow and Uncertainty." Oxford Economic Papers, 62, 2010b, 286-306.

Bell, V., and G. Young. "Understanding the Weakness of Bank Lending." Bank of England Quarterly Bulletin, Q4, 2010, 311-20.

Bernanke, B., and M. Gertler. "Inside the Black Box: The Credit Channel of Monetary Policy Transmission." Journal of Economic Perspectives, 9, 1995, 27-48.

Bernanke, B., M. Gertler, and S. Gilchrist. "The Financial Accelerator and the Flight to Quality." Review of Economics and Statistics, 78, 1996, 1-15.

. "The Financial Accelerator in a Quantitative Business Cycle Framework," in Handbook of Macroeconomics, Vol. 1C, edited by J. Taylor and M. Woodford. Amsterdam, The Netherlands: Elsevier Science, 1999.

Bernard, A., and F. Sjöholm. "Foreign Owners and Plant Survival." Working Paper 10039, NBER, 2003.

Blalock, G., P. J. Gertler, and D. Levine. "Financial Constraints on Investment in an Emerging Crisis." Journal of Monetary Economics, 55, 2008, 568-91.

Bloom, N. "Uncertainty and the Dynamics of R\&D." American Economic Review, 97, 2007, 250-55.

. "The Impact of Uncertainty Shocks." Econometrica, 74, 2009, 391-415.

Bloom, N., S. Bond, and J. Van Reenen. "The Dynamics of Investment under Uncertainty.” Working Paper 01/05, Institute for Fiscal Studies, London, 2001. 
. "Uncertainty and Investment Dynamics." Review of Economic Studies, 74, 2007, 391-415.

Blundell, R., and S. Bond. "Initial Conditions and Moment Restrictions in Dynamic Panel Data Models." Journal of Econometrics, 87, 1998, 115-43.

Bo, H., and R. Lensin. "Is the Investment Uncertainty Relationship Nonlinear? An Empirical Analysis for the Netherlands." Economica, 72, 2005, 307-31.

Bond, S., and J. Van Reenen. "Microeconometric Models of Investment and Employment," in Handbook of Econometrics, Vol. 6, edited by J. Heckman and E. Leamer. Amsterdam, The Netherlands: Elsevier Science, 2007.

Brav, O. "Access to Capital, Capital Structure, and the Funding of the Firm." Journal of Finance, 64, 2009, 263-308.

Bridges, S., and A. Guariglia. "Financial Constraints, Global Engagement, and Firm Survival in the UK: Evidence from Micro Data." Scottish Journal of Political Economy, 55, 2008, 444-64.

Bunn, P., and V. Redwood. "Company Accounts Based Modelling of Business Failures and the Implications for Financial Stability.” Working Paper 210, Bank of England, 2003.

Caballero, R. "Aggregate Investment," in Handbook of Macroeconomics, Vol. 1B, edited by J. Taylor and M. Woodford. Amsterdam, The Netherlands: Elsevier Science, 1999

Caglayan, M., and A. Rashid. "The Response of Firms' Leverage to Risk: Evidence from UK Public Versus Nonpublic Manufacturing Firms." Economic Inquiry, 52, 2014, 341-63.

Caglayan, M., S. Maioli, and S. Mateut. "Inventories, Sales Uncertainty, and Financial Strength." Journal of Banking and Finance, 36, 2012, 2512-21.

Carlsson, M. "Investment and Uncertainty: A Theory-Based Empirical Approach." Oxford Bulletin of Economics and Statistics, 69, 2007, 603-17.

Clementi, L., and H. Hopenhayn. "A Theory of Financing Constraints and Firm Dynamics." Quarterly Journal of Economics, 54, 2006, 229-65.

Denis, S., and P. Kannan. "The Impact of Uncertainty Shocks on the UK Economy." Working Paper 13/66, International Monetary Fund, 2013.

Desai, M., and K. Forbes. "Financial Constraints and Growth: Multinational and Local Firm Responses to Currency Depreciations." Review of Financial Studies, 21, 2008, 2857-88

Dixit, A. "Entry and Exit Decisions under Uncertainty." Journal of Political Economy, 97, 1989, 620-38.

Dixit, A., and R. Pindyck. Investment under Uncertainty. Princeton, NJ: Princeton University Press, 1994.

Dunne, T., M. Roberts, and L. Samuelson. "Patterns of Firm Entry and Exit in US Manufacturing Industries." Rand Journal of Economics, 19, 1998, 495-515.

Garcia-Vega, M., A. Guariglia, and M.-E. Spaliara. "Volatility, Financial Constraints, and Trade." International Review of Economics and Finance, 21, 2012, 57-76.

Geroski, P. "What Do We Know About Entry?" International Journal of Industrial Organization, 13, 1995, 421-40.

Ghosal, V. "Impact of Uncertainty and Sunk Costs on Firm Survival and Industry Dynamics." Working Paper 12, Wissenschaftszentrum Berlin (WZB), 2003.

Ghosal, V., and P. Loungani. "The Differential Impact of Uncertainty on Investment in Small and Large Businesses." Review of Economics and Statistics, 82, 2000, $338-43$.

Gilchrist, S., J. Sim, and E. Zakrajsek. "Uncertainty, Financial Frictions, and Investment Dynamics." Mimeo, Boston University, 2013.
Görg, H., and M.-E. Spaliara. "Financial Health, Exports, and Firm Survival: Evidence from UK and French Firms." Economica, 81, 2014, 419-44.

Görg, H., and E. Strobl. "Multinational Companies and Indigenous Development: An Empirical Analysis." European Economic Review, 46, 2002, 1305-22.

_. "Multinational Companies, Technology Spillovers and Plant Survival." Scandinavian Journal of Economics, 105, 2003, 581-95.

Guiso, L., and G. Parigi. "Investment and Demand Uncertainty." Quarterly Journal of Economics, 114, 1999, $185-227$.

Haddow, A., C. Hare, J. Hooley, and T. Shakir. "Macroeconomic Uncertainty: What Is It, How Can We Measure It and Why Does It Matter?" Bank of England Quarterly Bulletin, Q2, 2013, 100-09.

Hall, R. "Why Does the Economy Fall to Pieces after a Financial Crisis?" Journal of Economic Perspectives, 24, 2010, 3-20.

Hopehayn, R. "Entry, Exit and Firm Dynamics in Long Run Equilibrium." Econometrica, 60, 1992, 1127-55.

Huynh, K., and R. Petrunia. "Age Effects, Leverage and Firm Growth." Journal of Economic Dynamics and Control, 34, 2010, 1003-13.

Huynh, K., R. Petrunia, and M. Voia. "The Impact of Initial Financial State on Firm Duration across Entry Cohorts." Journal of Industrial Economics, 58, 2010, 661-89.

Jenkins, S. "Survival Analysis." Mimeo, University of Essex, 2005.

Jovanovic, B. "Selection and Evolution of Industry." Econometrica, 50, 1982, 3-37.

von Kalckreuth, U. "Exploring the Role of Uncertainty for Corporate Investment Decisions in Germany." Swiss Journal of Economics and Statistics, 139, 2000, 173-206.

Kashyap, A., J. Stein, and D. Wilcox. "Monetary Policy and Credit Conditions: Evidence from the Composition of External Finance." American Economic Review, 83, 1993, 78-98.

Leahy, J., and T. Whited. "The Effect of Uncertainty on Investment: Some Stylized Facts." Journal of Money, Credit, and Banking, 28, 1996, 64-83.

Lensink, R., H. Bo, and E. Sterken. "Does Uncertainty Affect Economic Growth? An Empirical Analysis." Review of World Economics, 135, 1999, 379-96.

Levin, A., F. Natalucci, and E. Zakrajsek. "The Magnitude and Cyclical Behaviour of Financial Market Frictions." Working Paper 2004-70, Board of Governors of the Federal Reserve System, 2004.

Michaely, R., and M. Roberts. "Corporate Dividend Policies: Lessons from Private Firms." Review of Financial Studies, 25, 2012, 711-46.

Mishkin, F. "Over the Cliff: From the Subprime to the Global Financial Crisis." Journal of Economic Perspectives, 25 , 2011, 49-70.

Mitchell, J., K. Mouratidis, and M. Weale. "Uncertainty in UK Manufacturing: Evidence from Qualitative Survey Data." Economics Letters, 94, 2007, 245-52.

Mizen, P., and S. Tsoukas. "The Response of the External Finance Premium in Asian Corporate Bond Markets to Financial Characteristics, Financial Constraints and Two Financial Crises." Journal of Banking and Finance, 36, 2012, 3048-59.

Morgan, D., B. Rime, and P. Strahan. "Bank Integration and State Business Cycles." Quarterly Journal of Economics, 119, 2004, 1555-84.

Patillo, C. "Investment, Uncertainty and Irreversibility in Ghana.” IMF Staff Papers, 45, 1998, 522-53. 
Santos, J. "Bank Corporate Loan Pricing Following the Subprime Crisis." Review of Financial Studies, 24, 2011, $1916-43$.

Tsoukas, S. "Firm Survival and Financial Development: Evidence from a Panel of Emerging Asian
Economies.” Journal of Banking and Finance, 35, 2011, $1736-52$

Zingales, L. "Survival of the Fittest or the Fattest? Exit and Financing in Trucking Industry." Journal of Finance, $53,1998,905-38$ 